\title{
A Study on Students' Affective Factors in Junior High School English Teaching
}

\author{
Biyi Zhu ${ }^{1} \&$ Yaping Zhou ${ }^{1}$ \\ ${ }^{1}$ Foreign Languages School, Zhejiang Ocean University, China \\ Correspondence: Yaping Zhou, Foreign Languages School, Zhejiang Ocean University, 18 Haiyuan Road, Dinghai \\ District, Zhoushan City, Zhejiang Province, 316000, China. Tel: 86-580-818-0286. E-mail: zyp@zjou.edu.cn
}

Received: March 8, 2012 Accepted: March 22, 2012 Online Published: July 1, 2012

doi:10.5539/elt.v5n7p33 URL: http://dx.doi.org/10.5539/elt.v5n7p33

\begin{abstract}
Affect is considered as aspects of emotion, feeling, mood or attitude which condition behaviors in second language acquisition. Positive affect is good for studying while negative affect will inevitably hinder learners' learning process. As we know, students in junior high school are special groups as they are experiencing great changes both in physiology and psychology. Their affect can be easily influenced by external and internal factors. Therefore, it is of vital importance to pay close attention to students' affective factors in English learning process, particularly to the negative ones. Based on the results of the previous research about affects in second language acquisition, the study finds that junior high school students have the following negative affective factors such as boredom, anxiety, hopelessness, inhibition and low self-confidence in their English learning. Then some suggestions for cultivating and improving students' affect are put forward in the hope of improving junior high school English teaching and learning.
\end{abstract}

Keywords: affective factor, junior high school, English teaching and learning

\section{Introduction}

Nowadays with the development of humanism, great importance is attached to the learners' non-intelligence factors. Humanistic educators advocate the importance of affect and the core position of learners. The function of the affect in language learning process has become a heated research topic in second language acquisition. Although educators and researchers have conducted a large number of studies to find out the relationship between language learning and the learners' affect, those studies are mostly done among the university students and little attention is paid to the junior high school students. For decades, Chinese teachers in junior high school have used the traditional way, the teacher-centered approach, in the teaching of a foreign language. In class, teachers appear as controllers, who are in complete charge of the class. They try to put everything into students' heads and students are seen as receptacles to be filled with knowledge. In this process, what teachers care most is how to improve students' marks on tests. Students' affect is generally ignored by teachers. What negative affect do junior high school students have? How can teachers apply humanistic approaches to English teaching to help students form positive affect? In order to address the above questions, we conducted a study to analyze the affective factors that students in junior high school have. After analyzing these factors, we put forward the suggestions to improve students' affect in junior high school English teaching.

\section{Literature Review}

Affect is the expression of one's inner world and attitude toward a certain thing, situation or experience. In language study, affect is one's attitude, emotion, feeling and mood. The affective factors include motivation, self-esteem, self-confidence, self image and empathy, etc. Stern (1983) indicates that the function of affect has the equivalent position of that of cognition. According to Arnold (1999), affect is composed of feelings, attitudes and motivations which will influence the process and result of language learning. Gardner et al (2004) also state that affective factors have some influence on language acquisition and achievement.

Attitude plays an important role in language learning process. A learner's attitude to the learning language will impact the learner outside the classroom. The study done by Burden (2004) showed that a positive attitude would motivate learners to achieve their learning goals. Stern (1983) stated that three components constituted attitude. The first is cognitive component, which means the belief to a certain aim. The second is affective component, which means likes and dislikes about an aim. The third is conation component, which means someone's intention and 
action about a certain aim. In English learning process, if a student is eager to learn a foreign language, this positive attitude is helpful for his study. On the contrary, if he regards English as a very difficult language and learning it as a waste of time, this negative attitude will inevitably restrain his English learning. The study done by Bahous, Bacha \& Nabhani (2011) told us that promoting positive student attitudes towards the learning language can motivate students to learn and become efficient in the target language.

Motivation is one of the important affective factors in learning process, which helps to determine the level of proficiency achieved by different learners. Motivation is thought of as "an inner drive, impulse, emotion, or desire that moves one to a particular action" (Brown, 2002, p. 152). Proper motivation can facilitate learners' learning process. In Krashen's opinion, the most ideal affect condition is that learners have high motivation and strong self-confidence, with which they can do better in second language acquisition (Krashen, 1982). Lambert and Gardner (1972) stated that there were generally two kinds of motivation: instrumental motivation and integrative motivation. The former emphasizes the function of utility and practicality of learning a language, which is often related with external goals such as finding a job, passing exams or reading newspapers of a foreign language. While the latter occurs when a learner desires to learn a language inwardly, wishing to learn more about the culture, customs and life styles of the speakers of that language. The results of the study conducted by Luo, Jian and Wang (2004) indicated that students' learning motivation had a strong influence on the study score and that intrinsic motivation and integrative motivation had positive relationship with learning outcome. Xu (2011) also stated in the study that language learning motivation was significantly correlated with the use of language learning strategies and teachers should assist students to achieve better results in English learning by understanding more about students' motivation and strategy use. Therefore, motivation is a key element affecting students' learning process and it is this internal drive that will encourage students to reach their aims.

\section{The Affective Factors of Students in Junior High School}

Junior high school students are special ones. First, they are experiencing great changes both in psychology and physiology. Their affect will easily be influenced by external and internal factors. Second, there are differences between primary school English teaching and junior high school English teaching. In primary school English teaching more emphasis is placed on the interest of English learning. Teachers will organize various kinds of activities to attract students' attention and improve their learning desire. While in junior high school, students must learn English systematically. More focuses are put on the teaching of grammar rules, sentence structures etc. Thus junior high school students may find it difficult to adapt to the new learning contents and learning styles. Therefore, whether students can hold positive affect or not will have decisive impact on their further study. In order to learn about the affective factors junior high school students have in their English learning, we did a study.

\subsection{The Subjects}

Grade Seven is the first year of junior high schooling in China. During the beginning of this new study life, students in Grade Seven may have various feelings and attitudes toward English learning. Therefore, the subjects of the study are chosen from Class Four and Class Eight in Grade Seven in City North Middle School, which is located in Fenghua, Zhejiang Province. There are altogether 49 students in Class Four and 45 in Class Eight, with 26 girls and 23 boys in one class and 22 girls and 23 boys in the other class. In Class Four, all students have learned English in primary school for 4 years while in Class Eight there are two boys who hadn't learned any English before.

\subsection{Instrument}

The data were collected through questionnaires, which were made up of two parts. In part A, students were asked to provide background information. In Part B, there were 15 questions intending to learn about the students' affective factors. The questionnaires were administered at the beginning of individual class periods with the help of the teacher on September 28, 2011. The students were informed of the purpose of the study. They were told that there was no right or wrong answer. Therefore the students just answered each question honestly and frankly according to their own opinion and behavior. In order to let students understand each statement clearly, we used the Chinese version of the questionnaire. We received all 94 questionnaires and analyzed the data manually.

\subsection{Results}

The results of the study are presented in the following tables. By analyzing the 15 questions in the questionnaire, we found that students in Grade Seven had three negative affects. They are boredom, anxiety and hopelessness. 


\subsubsection{Boredom}

Table 1. Descriptive Statistics for Learning Interest

\begin{tabular}{|c|c|c|c|}
\hline \multicolumn{2}{|l|}{ ITEM } & \multirow{2}{*}{$\begin{array}{c}\text { Class Four } \\
29 \%\end{array}$} & \multirow{2}{*}{$\begin{array}{c}\text { Class Eight } \\
22 \%\end{array}$} \\
\hline 1. My English performance in & Excellent & & \\
\hline primary school is & Good & $59 \%$ & $60 \%$ \\
\hline & Not bad & $12 \%$ & $18 \%$ \\
\hline & Bad & $0 \%$ & $0 \%$ \\
\hline \multirow{3}{*}{$\begin{array}{l}\text { 2. I feel the English knowledge } \\
\text { we are learning now is }\end{array}$} & Very difficult & $31 \%$ & $31 \%$ \\
\hline & Just so-so & $35 \%$ & $37 \%$ \\
\hline & Quite simple & $34 \%$ & $32 \%$ \\
\hline \multirow[t]{4}{*}{ 3. My interest in English study } & High interest & $24 \%$ & $18 \%$ \\
\hline & Moderate interest & $53 \%$ & $58 \%$ \\
\hline & Low interest & $18 \%$ & $20 \%$ \\
\hline & No interest & $5 \%$ & $4 \%$ \\
\hline \multirow{3}{*}{$\begin{array}{l}\text { 4. The knowledge being learned } \\
\text { now is almost the same as that in } \\
\text { primary school. }\end{array}$} & Agree & $80 \%$ & $73 \%$ \\
\hline & Neutral & $14 \%$ & $18 \%$ \\
\hline & Disagree & $6 \%$ & $9 \%$ \\
\hline \multirow{3}{*}{$\begin{array}{l}\text { 5. I feel bored if the activities are } \\
\text { not varied in class. }\end{array}$} & Agree & $90 \%$ & $93 \%$ \\
\hline & Neutral & $10 \%$ & $7 \%$ \\
\hline & Disagree & $0 \%$ & $0 \%$ \\
\hline
\end{tabular}

From Table 1, we can find that $71 \%$ students and $78 \%$ students in each class have moderate or low interest in English. What's more, 5\% students and 4\% students even show no interest in English. $80 \%$ students and $73 \%$ students think the knowledge they are learning now is quite similar to what they have learned in primary school. Nearly one third of the students think that the knowledge they are learning is quite simple. It is true that they have to restart learning English because there is no proper connection in textbooks. Students may feel the content in Book One and Two in junior high school English not so difficult because much of the knowledge is about greeting to someone, introducing one's family, asking time, location, describing persons etc. Therefore, most students will inevitably feel bored if they only mechanically practice it. They may think that they have already learned these sentences and grasped them very well. As a result, the repeated teaching of the same knowledge will make them think that English is very easy and not interesting. Gradually they will feel bored and lose the learning desire. Our result is similar to the study conducted by Huang (2010), which shows that more than half of the students in Grade Seven have already lost interest in English. If students feel bored, they are very likely to pay less attention to English learning and are reluctant to learn it whole-heartedly. This kind of negative affect is quite common among junior high school students, especially among some boys. Furthermore, if the teaching materials in junior high school English teaching are boring and unattractive, the students' attitude towards English will gradually turn to be negative. Therefore, in this special English teaching period it is very important for the teachers to do a lot of preparations to make teaching materials rich and interesting. Teachers should also take proper and efficient measures to make the beginning learning stage lively and attractive to reduce students' boredom because more than $90 \%$ of students say that they will feel bored if the activities in class are not varied.

\subsubsection{Anxiety}

Table 2. Descriptive Statistics for Students' Anxiety

\begin{tabular}{|c|c|c|c|}
\hline \multicolumn{2}{|l|}{ ITEM } & Class Four & Class Eight \\
\hline \multirow{2}{*}{$\begin{array}{l}\text { 6. I feel more nervous in English } \\
\text { classes than in other classes. }\end{array}$} & Agree & $43 \%$ & $45 \%$ \\
\hline & $\begin{array}{l}\text { Neutral } \\
\text { Disaoree }\end{array}$ & $47 \%$ & $\begin{array}{l}47 \% \\
8 \%\end{array}$ \\
\hline \multirow{3}{*}{$\begin{array}{l}\text { 7. I will get nervous when speaking in } \\
\text { English classes. }\end{array}$} & Agree & $65 \%$ & $69 \%$ \\
\hline & Neutral & $24 \%$ & $22 \%$ \\
\hline & Disagree & $11 \%$ & $9 \%$ \\
\hline \multirow{3}{*}{$\begin{array}{l}\text { 8. I will worry about making mistakes } \\
\text { in answering questions. }\end{array}$} & Agree & $84 \%$ & $91 \%$ \\
\hline & Neutral & $16 \%$ & $9 \%$ \\
\hline & Disagree & $0 \%$ & $0 \%$ \\
\hline \multirow{3}{*}{$\begin{array}{l}\text { 9. I feel nervous when taking English } \\
\text { tests. }\end{array}$} & Agree & $51 \%$ & $51 \%$ \\
\hline & Neutral & $41 \%$ & $49 \%$ \\
\hline & Disagree & $8 \%$ & $0 \%$ \\
\hline \multirow{3}{*}{$\begin{array}{l}\text { 10. I will always worry about doing } \\
\text { badly before English tests. }\end{array}$} & Agree & $35 \%$ & $42 \%$ \\
\hline & Neutral & $57 \%$ & $56 \%$ \\
\hline & Disagree & $8 \%$ & $2 \%$ \\
\hline
\end{tabular}


Anxiety may be considered as the most important and common affective factor in English learning. Scovel(1978) defined anxiety as a state of apprehension, a vague fear that is only indirectly associated with an object. It is related to the feelings of worry, doubt and frustration. Krashen(1982) in his famous Affective Filter Hypothesis pointed out that students with low anxiety, high motivation and self-confidence could get better achievement in learning process. However, from Table 2, we can find that $43 \%$ students and $45 \%$ students in each class feel more anxious when studying English than other subjects. A large number of them feel anxious when they are asked to answer questions before the whole class and may worry about giving the wrong answers. As for test anxiety, about half of the students feel anxious and nervous when taking exams.

The reasons for the anxiety are various. Some students are from rural areas and their education in primary schools may not be as good as that of those students from cities. They may have poor English knowledge and pronunciation. If they compare themselves with others in class and find that others have done better in the same activity or homework, they will feel anxious. Others feel that they will lose their faces when speaking before the whole class because of their poor pronunciation. What's more, burden and pressure from parents and teachers can also cause students' anxiety.

As we know, anxiety, especially too much anxiety, will have negative effect on students' English learning, which will produce worry, fear and self-doubt toward study. Anxiety is also a key factor that contributes to poor performances for students in English study.

3.3.3 Hopelessness

Table 3. Descriptive Statistics for Students' Hopelessness

\begin{tabular}{llcc}
\hline ITEM & & Class Four & Class Eight \\
\hline $\begin{array}{l}\text { 11. I dare not to speak English after I'm } \\
\text { laughed at by others in classes. }\end{array}$ & Neutral & $35 \%$ & $33 \%$ \\
& Disagree & $61 \%$ & $60 \%$ \\
\hline $\begin{array}{l}\text { 12. I always feel that others are better } \\
\text { than me in English. }\end{array}$ & Agree & $4 \%$ & $7 \%$ \\
\hline $\begin{array}{l}\text { 13. I want to learn English well, but will } \\
\text { feel hopeless if I can't get good scores }\end{array}$ & Agree & $29 \%$ & $31 \%$ \\
after I made great efforts. & Disagree & $49 \%$ & $40 \%$ \\
\hline $\begin{array}{l}\text { 14. I will regard myself as unable to } \\
\text { study English well after getting }\end{array}$ & Neutral & $23 \%$ & $29 \%$ \\
unsatisfactory results several times. & Disagree & $59 \%$ & $62 \%$ \\
\hline $\begin{array}{l}15 . \text { I will hate and give up studying if } \\
\text { the English teacher always points out }\end{array}$ & Neutral & $41 \%$ & $36 \%$ \\
my mistakes. & Disagree & $0 \%$ & $2 \%$ \\
\hline
\end{tabular}

Students in Grade Seven have different English levels after four years' primary school learning. Some students have unhappy and unsuccessful experiences about English in primary schools, so they may hold anxiety and fear toward junior high school English. From Table 3, it can be seen that nearly 30\% students in each class are reluctant to speak in English if they are often laughed at by their peers. More than half of the students will inevitably feel hopeless if they can not achieve good marks in exams even if they try their best. So, over $50 \%$ of students will label themselves as those who don't have talent for English learning.

In junior high school English, there are more vocabulary and grammar rules for students to remember. For example, a student with poor English foundation may spend a lot of time in remembering words and grammar rules. But if the result of the exams is discouraging, he or she will feel very disappointed and hopeless gradually. The repeated failure to get good scores in exams will largely discourage a student. They may feel that "I can't do it", "It seems that I always fail", "I am not so good when compared with my classmates".

Every student wants to learn English well and get satisfactory scores in English tests. But there are still quite a large number of students who have made great efforts but the performances in class and exams are always dissatisfactory. Gradually, they will feel quite hopeless and even don't have desire to learn English any more. 


\subsubsection{Other Affective Factors}

From the study, we find that students in junior high school have the affective factors of boredom, anxiety and hopelessness. However, from observation, we can find that the following affective factors are very common in students in junior high school.

Inhibition

It is very natural that with the increasing degree of self-awareness, human beings will build sets of defenses to protect the ego, if necessary by avoiding whatever might threaten the self (Arnold, 1999). Inhibition means to hold down the affective feelings and expression which one doesn't expect. Emotional inhibition of students can often be seen in junior high school classes.

As we all know, it is inevitable that we all make mistakes when learning a new language. Junior high school students have been learning English for some years and they are clearly aware that English learning involves the making of mistakes. But with the growing self-awareness, students will care a lot about their faces and are not willing to be laughed at by others in the class. Therefore, they will mistakenly regard mistakes made in English learning as threats to them. Thus they will try their best to build defenses to protect themselves by avoiding answering questions in classes.

Low Self-confidence and Self-esteem

Self-confidence and self-esteem are two affective factors that have strong links with the success of English learning.

Junior high school students are still in the stage of building their self-images. Classroom can be regarded as a place for students' mental and spiritual development. The increasing vocabularies and sentence patterns will inevitably increase the difficulty of English and strengthen their English learning burden. Remembering and correctly using grammar rules can be a hard job for some students. Naturally, a study gap can be produced among students in the same class. With the growth of students' self awareness, they take more and more notice of others' attitude towards them. They care much about how they are viewed by parents, teachers and classmates. They will see and judge their own image through others' attitude and responses to them. Their poor performances and bad marks may lead to negative assessment and attitude from teachers and parents, which increase their self-doubt about their own intelligence and ability. If teachers don't pay enough attention to the students with poor performances and don't offer necessary guidance to their English study, these students will feel that they are unnoticed and rejected by the teachers. As a result, they will gradually develop a negative self-image of themselves and believe that they have no learning potential and abilities. This kind of attitude and belief will greatly affect their self-confidence in the later English study.

\section{Suggestions for Improving Students' Affect in Junior High School}

A better understanding of students' affective factors is of primary importance in English teaching because positive affect can facilitate learning as well as teaching. The Humanistic Education Theory emphasizes the essential position of one's affect in education. Therefore, a successful and proper application of this theory in English teaching can bring about lots of benefits to English learning and teaching in junior high schools.

\subsection{Improving Students' Learning Motivation}

Students with high motivation are more willing to learn English well than others. The internal drive encourages students to study to their best abilities. Therefore, how to make students keep high learning motivation becomes the first challenge for teachers in junior high school.

\subsubsection{Meeting Students' Basic Needs}

According to Maslow's theory, a student will lack learning motivation if his basic needs are not met. For instance, a student with unhappy childhood usually has a strong desire for a secure environment because his needs for love and interpersonal closeness are not met. Students who don't do well in study and are often criticized by their parents at home or teachers in class will be diffident and hold low self-confidence and self-esteem. Therefore, teachers must first establish a secure environment where learners feel that they belong and where they can build up self-respect by receiving respect from others (Williams \& Burden, 2000).

A harmonious teacher-student relationship is quite essential in meeting students' basic needs. Rogers(1969) maintains that establishing rapport between teacher and student is a premise to create an environment where threatening factors can be reduced and students' images can be protected. Mutual respect and trust will make students more willing to cooperate with teachers in the classroom. If teachers can respect students' personalities and individual characters, students will feel that they are wanted and respected by the people around them. They will 
also feel that they are studying in a secure and free environment. When a student meets his basic needs, he will then perform his full potential and set goals to achieve self-actualization.

\subsubsection{Designing Activities Vividly to Arouse Students' Interest}

Interest is the best teacher. From the above analyses, we find almost half of the students have weak desire or even little interest in English. Humanistic educators advocate respecting learners' nature, keeping an eye on learners' interest, hobby and needs in learning process. It is important for teachers to arouse the students' interest in the beginning stage of new study life.

To keep students' interest in learning, teachers should try best to design appropriate activities. Let's take Section B "What Does He Look Like?" in Unit 7, Book 2 for example. As students have already learned how to describe a person in primary school, they will easily feel bored if teachers mechanically ask them to practice conversations in pairs after learning Section A. Therefore, it is better for teachers to teach Section B as follows:

\section{Unit 7 What Does He Look Like?}

\section{Section B (Second Period)}

(Having done some oral practices and exercises about the description of people, teachers then should design some tasks that students can practice what they have learned in a real situation.)

\section{Task 1: Catch me if you can!}

T: Class, it is very necessary for us to learn how to describe people's appearance. I will give you an example. This is John and he is a policeman. Last night, a little boy was killed by a man on the street. Now the police have found four suspects. They are Smith, Joe, David and White. One of them is the murderer. Can you help the police find out the bad man? Please listen to the tape and write down something about the murderer's appearance. (Then the teacher plays the tape that is pre-recorded and students listen and take notes).

(In doing this task, students will be highly motivated and show great interest in finding out the murderer.)

Task 2: Go to the police station to do a record.

T: Ok. Now it's your turn. Work in pairs. One acts as a policeman, and the other a witness. Choose one of the four persons to be your murderer and design a dialogue according to what we have learned. The rest of students should guess who the murderer is.

Model:

S1: What does he look like?

$\mathrm{S} 2$ : He is short and fat. His hair is brown and he has two blue eyes.

$\mathrm{T}$ : Who is the murder?

Ss: Joe.

Task 3: This is my QQ show.

Students are required to design their own QQ show. Draw a picture and then give a short description including hair, face, clothes and build.

(Nowadays, most students play $Q Q$. So they are quite familiar with $Q Q$ show and can have some words to say. What's more, the activity can also challenge their creativity.)

Junior high school students have their own physical and psychological characteristics. Teachers should attach great importance to their age and psychology. If teachers can make boring teaching materials interesting and attractive, students' initiative will be largely promoted when they have interest in what they are learning. Furthermore, with the development of science and technology, teachers can also make full use of the excellent teaching software to cultivate and stimulate students' interest.

\subsubsection{Cultivating Students' Self-efficacy}

According to Bandura(1997), self-efficacy is actually a person's own judgment of whether he is able to complete a certain task or not. He also points out that factors such as direct experiences, vicarious experiences, verbal persuasion and emotion will exert impact on self-efficacy. Self-efficacy is an important element of motivation. However, in our study, we find that junior high school students have shown the negative affects as low self-confidence, hopelessness, etc. These affects will lead to their low self-efficacy. As a result, some students may give up making efforts to learn English. 
Therefore, it is very important for teachers to adopt some measures to improve students' self-efficacy. First, teachers should give students tasks with proper difficulty so as to let them have experiences of success because positive language learning experiences can increase students' self-confidence in using English and strengthen their motivation to learn it. Second, teachers can ask students to observe others' positive attitude to study and their good performances in class. Through observation, students will change their attitude to themselves and may be more confident in their own ability to learn English well. With high self-efficacy, students are more willing to study by themselves.

\subsection{Reducing Student's Anxiety}

From the results of the study we can see that anxiety is one of the main affective factors junior high school students have in their English learning. Therefore, to obtain satisfactory teaching results, it is vital for teachers to adopt some valuable strategies to reduce students' anxiety depending on students' needs and learning background.

\subsubsection{Applying Cooperative Learning}

Cooperative learning is a kind of learning form in which students work together to "attain group goals that cannot be obtained by working alone or competitively" (Johnson, Johnson \& Holubec, 1998, p. 12). It is a way to make every student fully involved in classroom activities by cooperating with each other. Students will feel less anxious when doing group work or pair work. So teachers can learn to design appropriate activities for students to work in groups or in pairs so that students will feel at ease in learning. Now let's take the teaching of Unit Six, Book One for example. The main teaching objectives of this unit are to make students learn to talk about likes and dislikes and to make affirmative and negative statements. We design the teaching as follows:

\section{Step 1: Warming-up activity}

\section{Unit 6 Do You Like Bananas?}

T: What kind of food do you like best?

SA: Apple.

SB: chocolate

Step 2: Pair work: How many words can you add to the list?

\begin{tabular}{ll}
\hline Fruit & apple,... \\
\hline Vegetable & broccoli, ... \\
\hline Fast food & ice cream, ... \\
\hline
\end{tabular}

In this activity, the teacher asks students to fill in the blanks by themselves first and then work in pairs to add as many words as possible by asking and answering each other.

Step 3: Pair work: Dialogue

Teacher shows pictures of food and presents the sentence patterns to students.

Do you like ? ?

$$
\text { Yes, } \overline{\text { I do./ }} \text { No, I don't. }
$$

Students are required to work in pairs to practice the dialogue by giving answers according to their own opinions.

\section{Step 4: Group Work: Food Survey}

Teacher asks students to work in groups to make a food survey and record what one likes and dislikes.

\begin{tabular}{l}
\hline food $\quad$ likes \\
\hline tomatoes \\
hamburger \\
bananas \\
French fries \\
broccoli \\
salad \\
ice cream \\
Students discuss together and then give the class a report about what they like and don't like. \\
Sample report 1: "Hello, everyone! I like...and ... But I don't like ... or ...." \\
Sample report 2: "Hello, everyone! In our group Lucy likes ..., ... and ... but she doesn't like ....,... \\
or ..."
\end{tabular}


When students are involved in pair work or group work, they have more words to say. They feel less anxious when they express their ideas in a cooperative way than being asked to answer questions in front of the whole class. The student who is asked to give a report will also not feel as anxious as before because he knows that he represents not only himself, but also the whole group. As the range of being attended and assessed is expanded, his sense of anxiety will be reduced to some degree.

\subsubsection{Using Body Languages}

Body language is another effective way to reduce students' anxiety. Proper use of facial expressions and gestures can produce an optimistic and active atmosphere which is very beneficial for the good relationships between teachers and students. In junior high school English teaching, many materials can be taught with body language. For instance, some vocabulary related to facial expressions and actions such as smile, cry, stomachache, frown and so on. Some class instructions such as "Close your book" "Sit down" "Raise your hand" "Open your mouth" can also be made with the use of body language, which can make students easier to understand.

In our teaching, we often find that students feel very anxious when they are asked to stand up and answer questions which they don't know in class, and they will feel much more anxious if the whole class keeps silent. In such a case, if the teacher can use his eye contact to convey warmth and belief to make the student feel that he or she can do well or use other body language such as his mouth to give the student a hint, the student will feel more relaxed when answering the questions. When students finish a task successfully or answer questions correctly, teachers can give some positive feedback to them by means of a smile or a nodding head.

Body language can be a tool for teachers to deliver friendship and trust to students, establishing a more harmonious and relaxing atmosphere for study.

\section{Conclusion}

From the study, we can see that certain kind of negative affect may occur among students in junior high school. The most common ones are anxiety, boredom, hopelessness and low self-confidence. The reform of the educational system requires that students' role be put into the first priority in education. Teachers should be clear that students are not simply the receivers of the knowledge taught and students' affective development is of vital importance in learning. Therefore, it's very necessary and urgent for teachers to help students form positive affect. Teachers can improve students' learning motivation by meeting their basic needs, arousing their interest or cultivating their self-efficacy and reduce students' anxiety with the help of cooperative learning and proper use of body language. As long as students have interest in English, both teachers and students will find satisfaction in English teaching and learning. Students who hold positive affect are more likely to become ones of comprehensive quality.

\section{References}

Arnold, J. (1999). Affect in language learning. Cambridge: Cambridge University Press.

Bahous, R., Bacha, N. N., \& Nabhani, M. (2011). Motivating students in the EFL classroom: A case study of perspectives. English Language Teaching, 4(3), 33-42. http://dx.doi.org/10.5539/elt.v4n3p33

Bandura, A. (1997). Self-efficacy: The exercise of control. San Francisco: W. H. Freeman.

Brown, H. D. (2002). Principles of language learning and teaching. Beijing: Foreign Language Teaching and Research Press.

Burden, P. (2004). An examination of attitude change towards the use of Japanese in a university English 'conversation' class. RELC, 35(1), 21-36. http://dx.doi.org/10.1177/003368820403500104

Gardner, R. C., \& Lambert, W. E. (1972). Attitudes and motivation in second language learning. Rowley, Mass: Newbury House.

Gardner, R. C., Masgoret, A. -M., Tennant, J., \& Mihic, L. (2004). Integrative motivation: Changes during a year-long intermediate level language course. Language Learning, 54(1), 1-34. http://dx.doi.org/10.1111/j.1467-9922.2004.00247.x

Huang, Jianliang. (2010). Problems in the connection between primary school and junior high school English teaching and their counter-measures. Basic Education Research, (2), 28-30.

Johnson, D. W., Johnson, R. T., \& Holubec, E. J. (1998). Cooperation in the classroom. Edina, MN: Interaction Book Company.

Krashen, S. D. (1982). Principles and practice in second language acquisition. Southern California: University of Southern California. 
Luo, Jainwen, Jian, Xiaoming, \& Wang, Yuefang. (2004). Research on relationships among learning motivation, foreign language learning strategies and academic achievement. Research in Teaching, 27, 149-151.

Rogers, C. R. (1969). Freedom to learn. Columbus, Ohio: Charles Merrill.

Scovel, T. (1978). The effect of affect on foreign language learning: A review of the anxiety research. Language Learning, 28(1), 129-142. http://dx.doi.org/10.1111/j.1467-1770.1978.tb00309.x

Stern, H. H. (1983). Fundamental concepts of language teaching. Oxford: Oxford University Press.

Williams, M., \& Burden, R. L. (2000). Psychology for language teachers. Beijing: Foreign Language Teaching and Research Press.

$\mathrm{Xu}$, Xiuyan. (2011). The relationship between language learning motivation and the choice of language learning strategies among Chinese graduates. International Journal of English Linguistics, 1(2), 201-212. http://dx.doi.org/10.5539/ijel.v1n2p203 